\title{
Fipronil-amitraz-S-methoprene-triggered pemphigus foliaceus in 21 dogs: clinical, histological and immunological characteristics
}

\author{
Petra Bizikova*,$\dagger$, Keith E. Linder $\uparrow,+$ and Thierry Olivry*,$\dagger$ \\ * Department of Clinical Sciences, College of Veterinary Medicine, North Carolina State University, 1060 William Moore Drive, Raleigh, NC 27607, \\ USA \\ †Center for Comparative Medicine and Translational Research, North Carolina State University, 1060 William Moore Drive, Raleigh, NC 27607, USA \\ †Department of Population Health and Pathobiology, College of Veterinary Medicine, North Carolina State University, 1060 William Moore Drive, \\ Raleigh, NC 27607, USA
}

Correspondence: Petra Bizikova, Department of Clinical Science, College of Veterinary Medicine, North Carolina State University, 1060 William Moore Drive, Raleigh, NC 27607, USA. E-mail: pbiziko@ncsu.edu

\begin{abstract}
Background - A recently launched topical ectoparasiticide containing fipronil, amitraz and S-methoprene has been associated with the development of an acantholytic pustular dermatitis similar to that of Promeris-triggered pemphigus foliaceus (PF).
\end{abstract}

\begin{abstract}
Hypothesis/Objectives - Our objectives were to describe the clinical, histological and immunological features
\end{abstract} of this PF-like cutaneous adverse drug reaction.

Animals - Twenty-one dogs with a probable or definitive diagnosis of PF-like cutaneous adverse drug reaction were identified between May 2012 and February 2013.

Material and Methods - Histology, direct and indirect immunofluorescence were employed to address the
study objectives.

Results - Most dogs were middle-aged or older (median, 9 years) and of large size (median, $23 \mathrm{~kg}$ ). In six dogs (29\%), the PF-like lesions remained confined to the site of application, while 15 dogs (71\%) exhibited lesions at distant sites. One or two applications of the ectoparasiticide were sufficient to trigger PF-like lesions in seven $(33 \%)$ and six (29\%) dogs, respectively. Systemic signs were reported in nine dogs (43\%), all with lesions extending to sites distant from application areas. Tissue-bound antikeratinocyte lgG was detected in the lesional epidermis of eight of $19(42 \%)$ cases by direct immunofluorescence, while serum antikeratinocyte IgG was detected in 10 of $14(71 \%)$ cases by indirect immunofluorescence. Autoantibodies were found to target canine desmocollin-1 in 11 of 14 dogs (79\%), but not canine desmoglein-1, by indirect immunofluorescence on transfected cells. These immunological findings were similar in cases with localized and distant disease.

Conclusions and clinical importance - This new topical ectoparasiticide containing fipronil, amitraz and $S$-methoprene is capable of triggering the development of an acantholytic pustular dermatosis that is a clinical, histological and immunological close match for Promeris-triggered PF and naturally occurring autoimmune PF in dogs.

\section{Introduction}

Pemphigus foliaceus (PF) is an autoimmune skin disease of humans and animals directed against keratinocyte adhesion proteins critical for cell-cell adhesion in the upper epidermis. ${ }^{1,2}$ In dogs, PF represents the most common autoimmune skin disease, and it is characterized by superficial pustules that affect predominantly the face, nasal planum and ears. When more generalized, lesions on the trunk accompany the classic involvement of the face and/or footpads, the latter being a unique location present in approximately one-third of dogs with PF.

In canine PF, desmocollin-1 (DSC1) represents a major target autoantigen, and antibodies were detected in

Accepted 2 January 2014

Sources of Funding: This study was self-funded.

Conflict of Interest: No conflicts of interest have been declared. approximately $75 \%$ of screened cases. $^{3}$ Desmoglein-1 (DSG1), the second critical desmosomal protein in the upper epidermis and the major target autoantigen in human PF, appears to be recognized by only a minority of tested dogs with PF. ${ }^{4}$ Although the pathogenic significance of anti-DSC1 or anti-DSG1 IgG autoantibodies in canine PF has not yet been demonstrated, the pathogenic nature of the total antikeratinocyte IgG has been documented by passive transfer experiments in neonatal mice. $^{5}$

Factors that induce pathogenic autoantibodies in PF are largely unknown. While the genetic background plays an important role, one or more exogenous factors have been proposed to trigger this disease. ${ }^{6}$ Of the possible external factors, drugs are the best-recognized triggers of pemphigus in humans, ${ }^{7}$ and they are the most frequently proposed triggers in reports of canine PF ${ }^{8-12}$ In veterinary clinical settings, however, a systematic approach to determine the cause of a drug reaction (e.g. the use of 
the Naranjo drug probability scale) is rarely implemented and, therefore, most reported cases of drug-triggered canine PF remain unsubstantiated. An exception to this assertion is the recent report of drug-triggered PF by a flea preventative pesticide containing metaflumizone and amitraz (Promeris Duo; Pfizer, New York, NY, USA), in which $40 \%$ of affected dogs received the highest possible Naranjo score (i.e. 10 points) and were thereby diagnosed to have a definitive adverse drug reaction (ADR). Of the remaining dogs, one had a score of 9 points, while five dogs with localized and seven with distant disease were given a score of 7 (a probable ADR). ${ }^{12}$ Regrettably, owing to the complex composition of this product, the authors were unable to identify which of the component (s) of the formulation (metaflumizone, amitraz and/or vehicle) probably triggered PF in affected dogs. ${ }^{12}$

Interestingly, pesticides have been suggested as one of the possible triggers of pemphigus in people for decades. ${ }^{6,13-15}$ Possible pathomechanisms for pesticidetriggered pemphigus include the blocking of keratinocyte nicotinic acetylcholine receptor signalling involved in epidermal cohesion ${ }^{16}$ and/or an enhanced cytokine production and neoantigen formation leading to an immune imbalance and autoimmunity in genetically predisposed individuals. ${ }^{14}$ Although neither of the two insecticides included in Promeris Duo ${ }^{\circledR}$, metaflumizone or amitraz, is known to have cholinergic properties, the effect of these insecticides or the accompanying vehicle on keratinocytes and the immune system has not been investigated to determine which individual component, or their combination, could trigger PF. ${ }^{17-19}$

Certifect (Merial, Duluth, GA, USA) is a novel topical flea and tick preventative containing fipronil, amitraz and S-methoprene. ${ }^{20}$ Published studies preceding its release in 2011 reported high efficacy and no clinically relevant systemic or cutaneous ADR. ${ }^{21-24}$ However, shortly after the product was launched, the authors became aware of reports of possible PF-like drug reactions, similar to Promeris-triggered PF (PTPF). In order to characterize better the similarities or differences between these conditions, our objectives were to describe the clinical, histological and immunological features for 21 dogs that developed cutaneous lesions after application of Certifect.

\section{Materials and methods}

\section{Case selection}

Cases were identified through an e-mail request sent to the Vetderm Internet list (vetderm@lists.ncsu.edu). Dogs of any age, sex or breed were included if they presented with pustular or crusted lesions that first appeared at the site of application of Certifect. The referring veterinarians were asked to complete a questionnaire inquiring about the patient's signalment and relevant medical and drug history (e.g. history of autoimmune disease, preceding drug administration, history of Promeris Duo application, number and frequency of Certifect applications, time to development of lesions, lesion type and distribution). The Naranjo's scale was used to determine the drug reaction probability score, as previously reported. ${ }^{12,25}$ Only cases reaching at least five points (i.e. probable drug reactions) or higher were entered into this case series. Dogs with a previous history of an autoimmune skin disease were excluded. Dogs were excluded if they had received another systemic or topical drug for the first time during the month preceding the development of skin lesions. Based on the lesion distribution, the dogs were divided into the following two groups: (i) those with a localized phenotype (i.e. lesions exclusively localized at the site of application); and (ii) those with a generalized phenotype (i.e. lesions at areas distant but not contiguous to those seen at the application site).

\section{Histopathology}

Haematoxylin- and eosin-stained histological sections of skin biopsy samples collected by submitting clinicians were reviewed for histopathological changes. Biopsy slides were available for 19 of 21 cases, a cytology slide was available for one case, for which a skin biopsy procedure was not performed, and a biopsy report only was available for one case. Biopsy samples and the cytology sample were collected from Certifect application sites and from some distant skin sites that developed lesions.

For each case, sections were reviewed to identify any histopathological changes by a board certified veterinary pathologist (K.E.L.), including those previously described for PTPF. ${ }^{12}$ Histological changes were scored using a standard severity scale of minimal, mild, moderate and marked. Detailed histopathology methods are provided in Data S1 in Supplementary material.

\section{Detection of tissue-bound and circulating antikeratinocyte antibodies}

Using a previously described technique, paraffin sections were assessed for the presence of tissue-bound $\lg G, \lg M$ and $\lg A$ antibodies and activated C3 complement deposits between keratinocytes of the lesional skin, using previously described methods. ${ }^{12,26}$ The presence of tissue-bound antibodies and C3 complement was described based on the following criteria: (i) the pattern (i.e. intercellular or cytoplasmic); (ii) the epidermal depth (i.e. superficial, deep or panepidermal); and (iii) the extent (i.e. patchy to diffuse).

Indirect immunofluorescence testing of serum on healthy canine footpad and buccal mucosa tissue sections was used to detect antikeratinocyte IgG and IgA autoantibodies. Serum was collected from affected patients during active clinical disease. ${ }^{5,12}$ Serum samples from five healthy dogs served as negative controls. A positive result signifying the presence of circulating antikeratinocyte antibodies was considered if an intercellular, web-like fluorescence pattern could be detected in the epidermis of at least one of the tested substrates. The epidermal distribution of immunofluorescence was further characterized as superficial, deep or panepidermal.

\section{Detection of anti-desmocollin-1 and anti-desmoglein- 1 lgG antibodies}

All available sera were tested for immunoreactivity against recombinant canine DSC1 and DSG1 expressed on the surface of a DSC1and DSG1-transfected 293T kidney epithelial cell line as previously described. ${ }^{3}$ Additionally, all sera from affected dogs were tested on nontransfected 293T cells to rule out a nonspecific recognition of 293T cells unrelated to the transfection status. Transfected and nontransfected 293T cells were also tested with an anti-V5 tag antibody (Invitrogen, Carlsbad, CA, USA), which served as a positive control and to prove the successful transfection status, while five serum samples from healthy dogs served as negative controls. ${ }^{3}$ A positive result was characterized by stippled, membranous immunofluorescence.

\section{Results}

\section{Clinical summary}

Twenty-one dogs matching selection criteria were identified between May 2012 and February 2013. One case was from England; all others were from the USA. Most dogs were middle-aged or old (range, 5.5-13 years; median, 9 years) females (female-to-male ratio of 2.5) and of a large size (median, $23 \mathrm{~kg}$ ). The signalment data are summarized in Table 1. Nine of 21 dogs were Labrador retrievers, while the remaining 12 dogs were of different 
Table 1. Signalment and selected clinical data of dogs with the localized or generalized form of Certifect-triggered pemphigus foliaceus

\begin{tabular}{|c|c|c|c|c|}
\hline \multicolumn{3}{|c|}{ History, signalment, clinical signs } & \multirow{2}{*}{$\begin{array}{l}\text { Localized }(n=6) \\
9\end{array}$} & \multirow{2}{*}{$\begin{array}{l}\text { Generalized }(n=15) \\
9\end{array}$} \\
\hline Signalment & Age & Median (years) & & \\
\hline & Weight & Median (kg) & 26 & 22 \\
\hline & Sex & Male: female & $2: 4$ & $4: 11^{*}$ \\
\hline \multirow{6}{*}{$\begin{array}{l}\text { Certifect applications before } \\
\text { skin lesions }\end{array}$} & 1 Certifect application & Number (\%) & $2(33)$ & $5(33)$ \\
\hline & 2 Certifect applications & Number (\%) & $0(0)$ & $6(40)$ \\
\hline & 3 Certifect applications & Number (\%) & $2(33)$ & $1(7)$ \\
\hline & 5 Certifect applications & Number (\%) & $1(17)$ & $2(13)$ \\
\hline & 8 Certifect applications & Number (\%) & $0(0)$ & $1(7)$ \\
\hline & 15 Certifect applications & Number (\%) & $1(17)$ & $0(0)$ \\
\hline \multirow[t]{5}{*}{ Clinical signs (systemic) } & Systemic signs & Number (\%) & $0(0)$ & $9(60)$ \\
\hline & Lethargy & Number (\%) & n.a. & $9(60)$ \\
\hline & Fever & Number (\%) & n.a. & $6(40)$ \\
\hline & Anorexia & Number (\%) & n.a. & $6(40)$ \\
\hline & Seizure & Number (\%) & n.a. & $1(7)$ \\
\hline \multirow[t]{5}{*}{ Skin lesion distribution } & Site of application & Number (\%) & $6(100)$ & $15(100)$ \\
\hline & Face (dorsal nose or periocular) & Number (\%) & $0(0)$ & $8(53)$ \\
\hline & Ears & Number (\%) & $0(0)$ & $9(60)$ \\
\hline & Footpads & Number (\%) & $0(0)$ & $7(47)$ \\
\hline & Perianal and perigenital & Number (\%) & $0(0)$ & $4(27)$ \\
\hline
\end{tabular}

Abbreviation: n.a., not applicable.

* One intact female and two intact males.

breeds (whippet, Pomeranian, dachshund, Border collie, chow cross, Chihuahua cross, beagle, Chesapeake Bay retriever, miniature schnauzer, toy poodle and mixed breed).

Six of 21 dogs (29\%) exhibited lesions only at the site of application (localized phenotype), while 15 of 21 (71\%) developed lesions at the site of application as well as at distant sites not contiguous with the site of Certifect application (generalized phenotype). The location of the distant lesions and their frequency are described in Table 1. In both groups, the skin lesions consisted of pustules, erosions, crusts and alopecia; the latter two being the most commonly reported lesions (100 and 95\%, respectively; Figure 1). Systemic signs, such as fever, anorexia and lethargy, were seen exclusively in dogs with a generalized phenotype (Table 1).

None of these dogs had received Promeris Duo in the past or had received a new medication in the month preceding the development of the skin lesions. One of six dogs with the localized phenotype and two of 15 dogs with the generalized phenotype reached a Naranjo score value of 9 (i.e. a definitive ADR), while the remaining 18 dogs scored 6 points (i.e. a probable ADR).

The number of Certifect applications prior to disease development varied from one to 15 , with a median of three and two for the localized and generalized phenotypes, respectively. One or two applications of Certifect were sufficient to trigger disease in seven (33\%) or six (29\%) dogs, respectively (Table 1 ). All dogs for which the 'time to lesion development' was reported developed lesions within a month of the last Certifect application. In two dogs with the localized phenotype, the owner noticed some skin lesions 1 day after the application of Certifect, while the other two localized cases, for which such information was provided, developed lesions within 14 and 29 days postapplication. Three of the dogs with the generalized phenotype developed lesions within a week of Certifect application, while in five dogs the lesions appeared between 14 and 28 days postapplication.
The treatment histories were available for all 21 dogs (Table S1 in Supplementary material). Eighteen dogs received oral glucocorticoids at an anti-inflammatory (13 of 18) or immunosuppressive dosage (five of 18) either as a monotherapy (five of 18) or in combination with other systemic (eight of 18) or topical immunomodulatory drugs (two of 18) or with a combination of both (three of 18). In the remaining three dogs, ciclosporin was the only systemic medication administered to treat the dog.

Follow-up information was available for all dogs (range, 2-11 months; median, 6 months). Seventeen of 21 dogs reached full disease remission, 11 of which did not require further treatment. The median time to complete remission for both groups was 2 months (Table S2 in Supplementary material). At the time of writing, eight of 21 dogs (three localized and five generalized) were still undergoing treatment with systemic glucocorticoids (two of eight), glucocorticoids and azathioprine (two of eight), azathioprine (two of eight) or ciclosporin (two of eight). Of note, five of eight dogs still receiving medications have only been treated for 2 (three of five), 6 (one of five) or 6 months (one of five); four of them being in full disease remission.

Two of the 15 dogs with generalized phenotype were euthanized. One of these dogs was euthanized due to a presumed gastric ulcer perforation, possibly related to treatment with prednisone and azathioprine. The other dog was treated with prednisone and ciclosporin, but euthanasia was elected several weeks after initial presentation.

\section{Histopathology}

Microscopic changes observed at local skin application sites for Certifect were similar to those that developed at distant skin sites. Evidence of epidermal pustule formation (Figure 2a) with keratinocyte acantholysis was present in 18 of 19 cases for which histology was available and via cytology or histopathology report in one case each. In 16 cases, pustules were active and, in two 

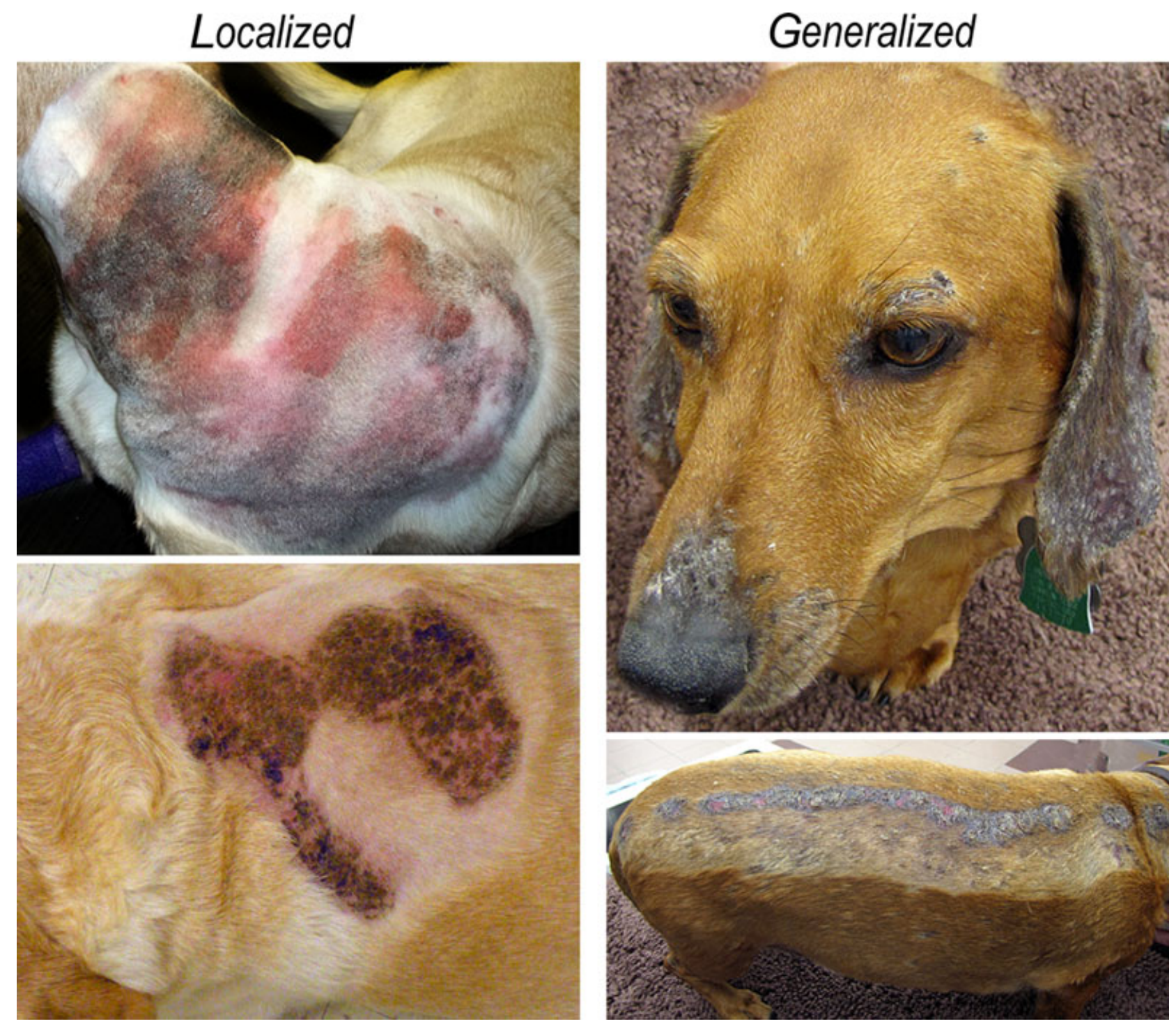

Figure 1. Representative clinical lesions of dogs with the localized and generalized phenotypes of Certifect-triggered pemphigus foliaceus. All three dogs (two localized and one generalized) developed the first lesions at the site of application. These consisted of erythema, erosions, alopecia and crusting. In addition, the dog with the generalized phenotype developed alopecia and crusts at sites distant from the application site. Courtesy of Valerie Fadok, Nicole Marquardt and Mike Mihlfried.

cases, only resolving pustules were captured as crusts containing 'ghost' acantholytic keratinocytes.

Both small and large subcorneal pustules were often present in the same case (12 of 16) but, in a few cases, pustules were only small (one of 16) or only large (three of 16), the latter spanning more than one follicular infundibulum. Pustules were predominately subcorneal, involved only the superficial epidermis (12 of 16), occasionally extended deep (Figure 3 ) to near the basal layer (four of 16), and involved follicular infundibula (Figures 2c and 3 ) in several cases (12 of 16) where pustules were mostly minimal to mild and rarely marked. Pustules contained minimal to marked numbers of acantholytic keratinocytes, which only occasionally occurred in clusters (Figure 3), and could be found in several cases with an eosinophilic perinuclear ring, which was presumed to consist of collapsed intermediate filaments (Figure 2c). Pustules contained neutrophils, and it was common to find minimal to marked numbers of eosinophils (Figure 2c) within pustules (13 of 16). Pustules evolved to crusts, which were only sometimes layered (Figure 2d) and often contained dried 'ghost' acantholytic cells (Figure 2b). A few crusts contained minimal to mild haemorrhage. Minimal to mild, and rarely moderate, spongiosis was common (Figure 3), often at the ventral margins of pustules. Epidermal necrosis bordered a few pustules (six of 16) and was minimal to mild, observed as a thin rim, one or two cells thick, or was rarely moderate to marked, observed as partial to full-thickness epidermal necrosis (Figure $4 a, b$ ). In these and other cases, all or some acantholytic keratinocytes often appeared prematurely necrotic (Figure 3, inset). Keratinocyte apoptosis was minimal (five to 10 cells) in the stratum spinosum and granulosum of the epidermis in two cases, where it was near a pustule, and was accompanied by rare lymphocytic satellitosis in one case and neutrophils in one case. Irregular epidermal hyperplasia in all cases ranged from minimal to marked, while most cases had minimal to mild, basket weave to laminated, orthokeratotic hyperkeratosis with minimal patchy parakeratosis. Inter- 

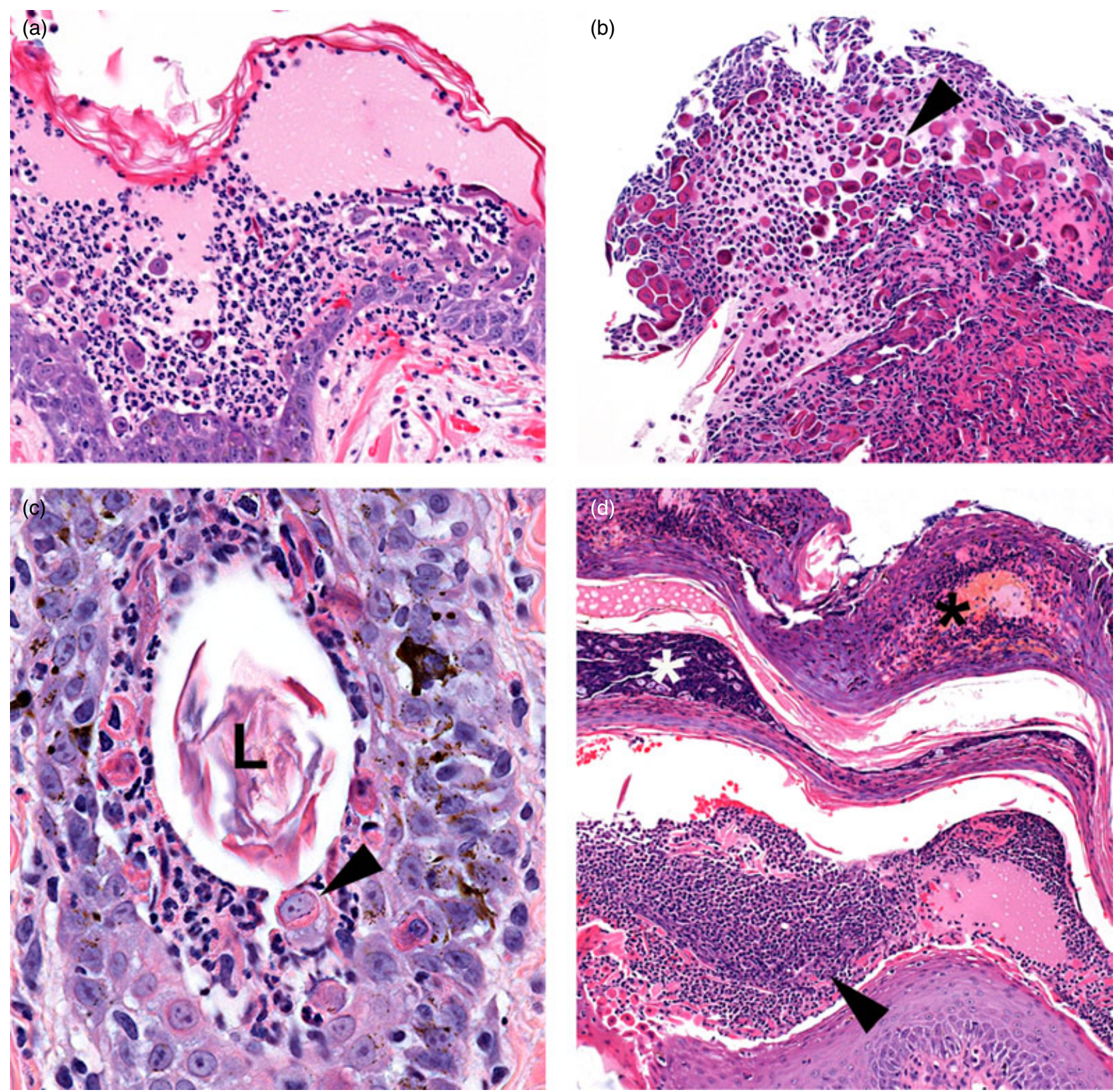

Figure 2. Photomicrographs of Certifect-triggered pemphigus foliaceus. (a) A large subcorneal pustule contains several acantholytic keratinocytes and numerous neutrophils. (b) A crust, formed from a resolved pustule, contains numerous 'ghost' acantholytic keratinocytes (arrowhead). (c) The deep infundibulum of a hair follicle contains a subcorneal pustule with eosinophils and acantholytic keratinocytes, some with a condensed perinuclear eosinophilic ring (arrowhead). $L$ is a hair follicle lumen. (d) A layered crust containing resolved pustules (asterisks) over a newly forming pustule (arrowhead) indicates waves of pustules in the same location. Haematoxylin and eosin.

estingly, two cases had moderate, near diffuse parakeratosis. Shallow erosions were common, and ulcers were found in fewer cases (five of 19), sometimes associated with pustules and epidermal necrosis.

In the dermis, perivascular to interstitial inflammation was predominately lymphoplasmacytic and often contained neutrophils in mild to moderate numbers in cases with active pustule formation. Eosinophils were common in the dermis (13 of 19) and ranged from a few individual cells to large numbers that dominated the inflammatory infiltrate. Dermal oedema was absent in some cases and ranged from minimal to marked in others. Mild haemorrhage was occasionally captured.

(C) 2014 ESVD and ACVD, Veterinary Dermatology, 25, 103-e30.

\section{Detection of tissue-bound antikeratinocyte} antibodies by direct immunofluorescence

Paraffin-embedded skin sections from 19 cases were available for detection of keratinocyte-bound $\lg G, \lg A$ and IgM antibodies and activated C3 using direct immunofluorescence (Table 2). Deposition of IgG was detected in eight of 19 dogs, and it was characterized by patchy (four of eight) or diffuse web-like fluorescence (four of eight) outlining the keratinocyte contours of the upper (six of eight; Figure 5), lower (one of eight) or the entire epidermis (one of eight). Deposition of lgM was detected in the epidermis of three dogs with either a patchy, intercellular (one of three) or cytoplasmic pattern (two of three) localized below a pustule or crust. Activated complement and 


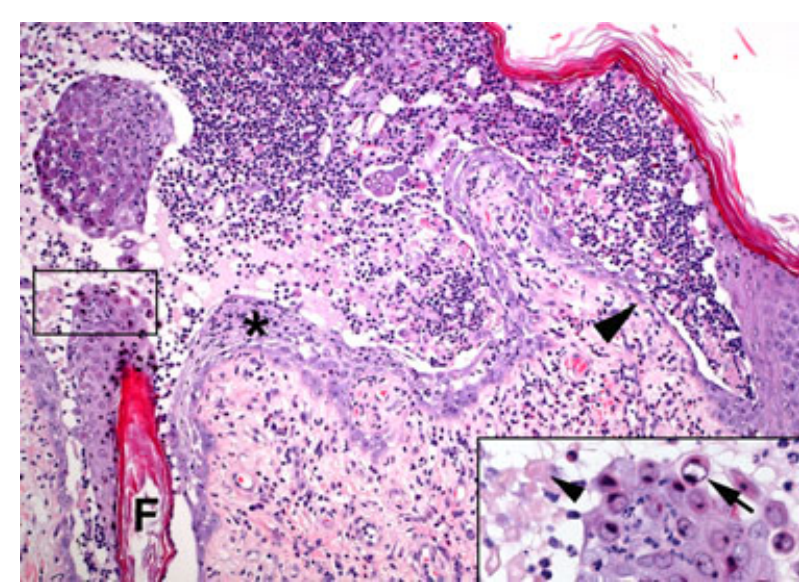

Figure 3. Photomicrograph of Certifect-triggered pemphigus foliaceus. A large subcorneal pustule extends deep in the epidermis to the basal layer (arrowhead), is bordered by spongiosis (asterisk), contains small and large 'rafts' of acantholytic keratinocytes and extends into a hair follicle (F). The inset illustrates both viable (arrow) and necrotic acantholytic keratinocytes (arrowhead). Haematoxylin and eosin.

$\lg \mathrm{A}$ were detected in one case as patchy, intercellular deposits in the epidermis below pustules or crusts.

\section{Detection of circulating antikeratinocyte antibodies by indirect immunofluorescence}

Serum sampels from 14 dogs were available for detection of circulating antikeratinocyte $\lg G$ and $\lg A$ antibodies (Table 3). Circulating IgG antibodies binding to keratinocytes of the footpad epithelium were detected in sera of two of three and eight of 11 dogs with the localized and generalized phenotypes, respectively. An intercellular lgG immunofluorescence pattern was observed in the superficial layers of the epidermis in all but one case with the localized phenotype, in which the IgG deposition was localized to the basal and lower stratum spinosum levels (Figure 5). Circulating IgA antibodies binding to keratinocytes of the footpad epithelium were detected in four of 14 sera. Three of the four samples exhibited cytoplasmic deposition of IgA localized in the basal and lowest stratum spinosum layers, while serum from one dog with the generalized phenotype yielded an intercellular fluorescence pattern in the upper layers of the epithelium. For all 14 sera, neither IgG nor IgA antibody binding was detected on epithelial cells of buccal mucosa.

\section{Detection of anti-desmocollin-1 and anti-desmoglein- 1 IgG antibodies \\ Anti-DSC1 lgG antibodies were detected in two of three and nine of 11 sera from dogs with the localized and gen- eralized phenotypes, respectively (Table 3 and Figure 5). Ten of these 11 sera with anti-DSC1 IgG corresponded to those with antikeratinocyte $\lg G$ antibodies reported in the section above. The last serum sample with anti-DSC1 IgG antibodies exhibited negative results on indirect immuno- fluorescence using canine footpad and buccal mucosa.}

\section{Discussion}

Our results support Certifect-triggered ADR being another contact-triggered PF that closely resembles the previously described PTPF. ${ }^{12}$ Indeed, skin lesions characterized by pustules, erosions and crusts at the application site only (localized phenotype) or at distant skin areas in addition to the application site (generalized phenotype) were identical to those of PTPF. Although systemic signs such as lethargy, fever and anorexia were reported in both entities, it appears that these were less common in Certifect-triggered PF (CTPF) cases (64\% in PTPF versus $43 \%$ in CTPF) and none was reported in the localized form of CTPF. As in PTPF, females were more numerous in this study (71\%); however, a reference population was not available to determine the relative risk more precisely. In contrast to the PTPF, in which more than $90 \%$ of cases were large-breed dogs, CTPF cases showed more variability in size (62\% large, $24 \%$ medium and $14 \%$ small).

Immunosuppressive treatment (e.g. prednisone/prednisolone $\geq 2 \mathrm{mg} / \mathrm{kg} / \mathrm{day}$ and/or azathioprine) was required
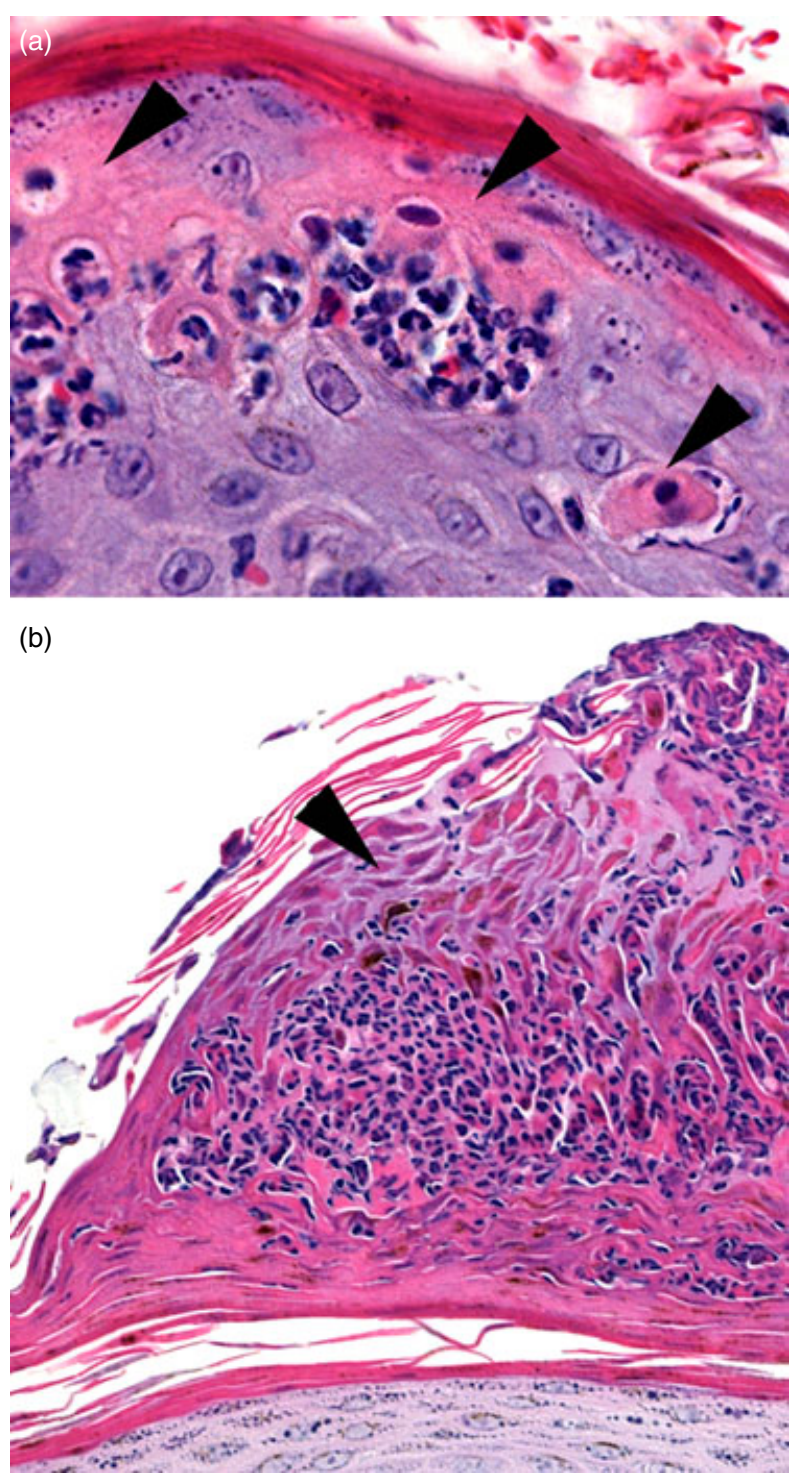

Figure 4. Photomicrograph of Certifect-triggered pemphigus foliaceus. (a) A very small pustule in the upper epidermis forms in association with keratinocyte necrosis (arrowheads). (b) A resolved epidermal pustule forms a crust, which contains a large entrapped portion of necrotic epidermis at its margin (arrowhead). The necrosis depicted in images (a) and (b) is not typical of naturally occurring pemphigus foliaceus. Haematoxylin and eosin. 
Table 2. Detection of tissue-bound antibodies and complement in the skin of dogs with the localized or generalized form of Certifecttriggered pemphigus foliaceus

\begin{tabular}{|c|c|c|c|}
\hline \multicolumn{2}{|c|}{$\begin{array}{l}\text { Direct } \\
\text { immunofluorescence }\end{array}$} & \multirow{2}{*}{$\begin{array}{l}\text { Localized }(n=5) \\
3(60)\end{array}$} & \multirow{2}{*}{$\frac{\text { Generalized }(n=14)}{5(36)}$} \\
\hline $\lg G$ & Number (\%) & & \\
\hline $\lg M$ & Number (\%) & $1(20)$ & $2(14)$ \\
\hline $\lg A$ & Number (\%) & $0(0)$ & $1(7)$ \\
\hline $\mathrm{C} 3$ & Number (\%) & $0(0)$ & $1(7)$ \\
\hline
\end{tabular}

to treat 59 and $43 \%$ of dogs with PTPF and CTPF, respectively. In PTPF, the need for immunosuppression in the localized form was nearly twice less likely than in dogs with the generalized form. In contrast, the use of immunosuppression in CTPF was nearly equal between the localized and generalized groups (50 and 40\%, respectively). This difference could be explained by a more proactive treatment approach by veterinarians familiar with PTPF, with the goal of achieving fast remission of clinical signs and to prevent potential progress into the generalized phenotype. Indeed, complete remission of clinical signs was observed in $81 \%$ of dogs with CTPF, with a median time to complete remission being approximately 2 months for both localized and generalized phenotypes. Moreover, in 11 of 21 dogs (52\%), drugs could be fully discontinued. A similar rate of complete remission (86\%) was reported in the PTPF case series but, in contrast to the CTPF, drugs were completely discontinued in a greater number of cases, 16 of 21 dogs (76\%). This difference could be explained by the longer duration of followup in the PTPF study (median, 15 and 6 months for PTPF and CTPF, respectively).

Distinct differences in the types of histopathological skin lesions from dogs with CTPF, PTPF and natural PF were not discovered. The morphological spectrum and extent of tissue changes overlapped between these con- ditions. Therefore, histopathology by itself cannot readily distinguish between these three entities, and a thorough history and clinical assessment are crucial to render the correct diagnosis and provide an appropriate prognosis, the latter of which is poorer for natural PF. Information about topical drug application and any relationship to skin lesion development at the application site is needed. Biopsy and/or cytology of any contact-associated skin lesions caused by topically applied pesticide is recommended to look for evidence of pustule formation and keratinocyte acantholysis. In the CTPF, epidermal necrosis in association with pustule formation and premature necrosis of acantholytic keratinocytes were identified and are possible features that differentiate natural PF, if present. Additional findings of ulceration of the epidermis and minimal to mild haemorrhage in the crusts of some CTPF lesions also support previous full-thickness necrosis of the epidermis, which is not typical of natural PF, and might be indirect indicators of necrosis contributing to CTPF lesions. Further investigations are warranted to address patterns of necrosis in CTPF and their value as differentiating features from that of the natural PF.

Similar to cases of PTPF and natural PF, tissue-bound and circulating antikeratinocyte antibodies were detected in samples from dogs with CTPF independently of their phenotype status. Indeed, the percentage of dogs with circulating antikeratinocyte antibodies binding to the canine footpad substrate was very similar between dogs with localized and generalized CTPF phenotypes, which could have been the result of a small number of samples from dogs with the localized phenotype. These findings were further supported by the detection of circulating anti-DSC1 IgG antibodies in all sera with detectable tissue-bound or circulating antikeratinocyte antibodies. In general, the percentage of sera with anti-DSC1 reactivity in CTPF $(71 \%)$ was similar to that reported for PTPF $(75 \%)$ and natural PF (82\%) in the recent publication
Tissue-bound $\lg G$

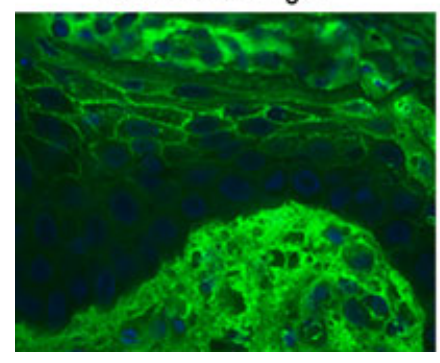

Circulating $\lg G$

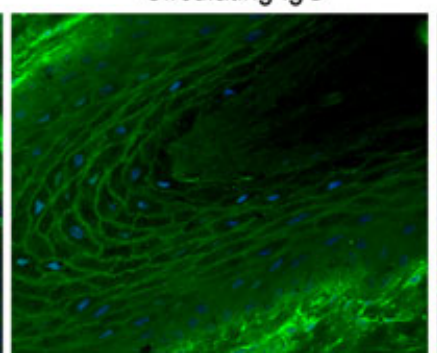

Anti-DSC1 lgG

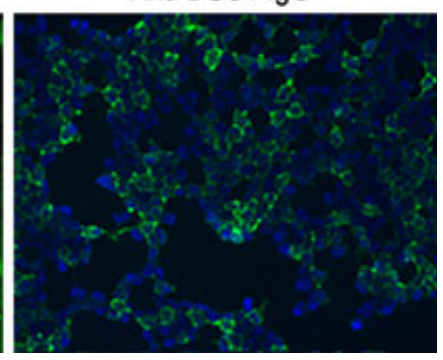

Figure 5. Certifect-triggered pemphigus foliaceus. A composite depicting positive results of direct and indirect immunofluorescence studies demonstrating tissue-bound and circulating antikeratinocyte and anti-desmocollin-1 (anti-DSC1) IgG autoantibodies.

Table 3. Detection of circulating antikeratinocyte and anti-desmocollin-1 and anti-desmoglein-1 lgG antibodies in the serum of dogs with the localized or generalized form of Certifect-triggered pemphigus foliaceus

\begin{tabular}{|c|c|c|c|c|c|}
\hline Indirect immunofluorescence & & & & Localized $(n=3)$ & Generalized $(n=11)$ \\
\hline \multirow[t]{4}{*}{ Healthy canine tissue substrates } & $\lg G$ & Footpad & Number (\%) & $2(67)$ & $8(73)$ \\
\hline & & Buccal mucosa & Number (\%) & $0(0)$ & $0(0)$ \\
\hline & $\lg \mathrm{A}$ & Footpad & Number (\%) & $2(67)$ & $2(18)$ \\
\hline & & Buccal mucosa & Number (\%) & $0(0)$ & $0(0)$ \\
\hline \multirow[t]{2}{*}{ Cadherin-transfected cell substrates } & $\lg G$ & Desmocollin-1 & Number (\%) & $2(67)$ & $9(82)$ \\
\hline & & Desmoglein-1 & Number (\%) & $0(0)$ & $0(0)$ \\
\hline
\end{tabular}


establishing this protein as a major canine PF autoantigen. ${ }^{3}$ The clinical, histological and immunological similarity between CTPF and natural PF suggests a shared pathogenesis for these conditions.

Little is known about the exact trigger leading to the antibody production and disease development in the PTPF and CTPF. Genetic background, immunological or hormonal status are all well-known factors that can influence development of natural pemphigus in humans. Considering the large number of dogs treated with Promeris Duo or Certifect and the relatively low number of reported cases of PTPF or CTPF, it is likely that these or other patient-specific factors are also involved in the development of these two conditions. It is currently unknown which of the components (amitraz, metaflumizone, fipronil or vehicles) or any combination thereof represents the trigger. To complicate this analysis, there is a recent report of contact-triggered PF after administration of yet another flea preventative containing completely different drugs (dinotefuran, pyriproxyfen and permethrin; Vectra 3D; Ceva Animal Health, Lenexa, KS, USA). ${ }^{27}$

We speculate that insecticide contact-triggered pemphigus could be elicited by several mechanisms, including a systemic effect via absorption of the drug or by a direct alteration of the skin and formation of neoantigens, which, in susceptible individuals, could lead to a secondary production of autoantibodies. ${ }^{28}$ Other mechanisms proposed in development of contact pemphigus comprise allergic contact reactions with enhanced cytokine release, activation or inhibition of enzymes involved in cell adhesion or an imbalance in cholinergic control of keratinocyte adhesion. ${ }^{7,16}$

Interestingly, two dogs in this series developed local skin lesions within a day and one within a week after receiving the first dose of Certifect. Given that the onset of the lesion was based on the owners' reports, it is unknown whether these early lesions corresponded to the acantholytic pustules seen in the CTPF or if they represented local inflammation with keratinocyte injury. The latter option is more likely, because the production of autoantibodies requires at least 3-4 weeks after the primary sensitization. ${ }^{29}$ However, the rapid appearance of skin lesions could support the hypothesis of an initial keratinocyte injury leading to the release of autoantigens and/or to the establishment of a pro-inflammatory cytokine milieu, which, in predisposed dogs, could trigger a true autoimmune response.

Further studies to investigate factors such as the effect of the vehicles with or without the concurrent presence of the active ingredients on skin keratinocytes or adhesion proteins or on the induction of pro-inflammatory cytokines could help to uncover the mechanism by which these products cause this unique cutaneous ADR. One should, however, bear in mind that factors other than the drug are likely to be important for the development of this rare disease (e.g. genetic background, immunological or hormonal status and environment).

In conclusion, CTPF represents another contacttriggered $\mathrm{PF}$, the awareness of which should be disseminated among veterinarians and owners. As a result of the variability in the number of monthly applications from one-to 15 before the disease onset, it is impossible to predict whether or not a dog might develop this cutaneous ADR. However, because skin lesions developed at the site of application within the first 2 weeks in more than half of the dogs (67\%), the owners should be advised to observe application sites daily and to report any visible changes. Treatment should include a thorough washing of the dog (especially in early detected cases) and concurrent anti-inflammatory or immunosuppressive therapy as deemed appropriate. The choice of immunosuppression will depend on the severity of the disease and the response to an anti-inflammatory treatment (if previously tried). Topical glucocorticoids might be of help to manage focal lesions in both localized and generalized phenotypes

Veterinarians and veterinary pathologists should be aware that histopathology does not readily distinguish natural PF from PTPF or CTPF and, therefore, that a thorough clinical history is critical for differentiating these conditions and for prognosis.

Finally, these unique cutaneous ADRs present an opportunity for studying contact-triggered pemphigus, which is a very rare condition in human medicine. Unravelling the mechanism of disease development would further increase the knowledge about keratinocyte adhesion and pemphigus development in veterinary and human dermatology; it would also help in designing flea preventatives with minimal risk for development of such unique cutaneous ADRs.

\section{Acknowledgements}

The authors thank Wayne Banning, Karin Beale, Joseph Bernstein, Kevin Byrne, Trae Cutchin, Catherine Etherington, Valerie Fadok, Allison Foster, Blair Johnson, Klaus Loft, Lindsay McKay, Nicole Marquardt, Victoria Martinez, Mike Mihlfried, Tim Nuttall, Wes Rice, Harold Richardson, Sandra Sargent, Leslie Sauber, Helen Scott and Randall Thomas for providing the case material for this study. The authors would also like to thank Stan Dunston and Lisa Mamo for performing the immunofluorescence experiments.

\section{References}

1. Olivry T. A review of autoimmune skin diseases in domestic animals: I - superficial pemphigus. Vet Dermatol 2006; 17: 291305.

2. James KA, Culton DA, Diaz LA. Diagnosis and clinical features of pemphigus foliaceus. Dermatol Clin 2011; 29: 405-412, viii.

3. Bizikova P, Dean GA, Hashimoto $T$ et al. Cloning and establishment of canine desmocollin-1 as a major autoantigen in canine pemphigus foliaceus. Vet Immunol Immunopathol 2012; 149: 197-207.

4. Olivry T, LaVoy A, Dunston SM et al. Desmoglein-1 is a minor autoantigen in dogs with pemphigus foliaceus. Vet Immunol Immunopathol 2006; 110: 245-255.

5. Olivry T, Dunston SM, Walker RH et al. Investigations on the nature and pathogenicity of circulating antikeratinocyte antibodies in dogs with pemphigus foliaceus. Vet Dermatol 2009; 20: 42-50.

6. Brenner S, Mashiah J, Tamir E et al. PEMPHIGUS: an acronym for a disease with multiple etiologies. Skinmed 2003; 2: 163-167.

7. Brenner S, Goldberg I. Drug-induced pemphigus. Clin Dermatol 2011; 29: 455-457.

(C) 2014 ESVD and ACVD, Veterinary Dermatology, 25, 103-e30 
8. Medleau L, Shanley KJ, Rakich PM et al. Trimethoprim-sulfonamide-associated drug eruptions in dogs. J Am Anim Hosp Assoc 1990; 26: 305-311.

9. Noli C, Koeman JP, Willemse T. A retrospective evaluation of adverse reactions to trimethoprim-sulfonamide combinations in dogs and cats. Vet $Q 1995 ; 17$ : 123-128.

10. White SD, Carlotti DN, Pin D et al. Putative drug-related pemphigus foliaceus in four dogs. Vet Dermatol 2002; 13 : 195-202.

11. Horvath C, Neuber A, Litschauer B. Pemphigus foliaceus-like drug reaction in a 3-month-old crossbreed dog treated for juvenile cellulitis. Vet Dermatol 2007; 18: 353-359.

12. Oberkirchner U, Linder KE, Dunston SM et al. Metaflumizoneamitraz (Promeris)-associated pustular acantholytic dermatitis in 22 dogs: evidence suggests contact drug-triggered pemphigus foliaceus. Vet Dermatol 2011; 22: 436-448.

13. Tsankov N, Kazandjieva J, Gantcheva M. Contact pemphigus induced by dihydrodiphenyltrichlorethane. Eur J Dermatol 1998; 8: 442-443

14. Wohl Y, Goldberg I, Brenner S. Chlorpyrifos as a possible pemphigus-inducing pesticide - an in vitro study. J Am Acad Dermatol 2004; 50(Suppl): 94 (abstract).

15. Fisher KR, Higginbotham R, Frey $J$ et al. Pesticide-associated pemphigus vulgaris. Cutis 2008; 82: 51-54.

16. Grando SA. Cholinergic control of epidermal cohesion. Exp Dermatol 2006: 15: 265-282.

17. Rust MK, Rugg D, Rock D. Metaflumizone - a new ectoparasiticide for dogs and cats. Vet Parasitol 2007; 150: 175-176.

18. Salgado VL, Hayashi JH. Metaflumizone is a novel sodium channel blocker insecticide. Vet Parasitol 2007; 150: 182-189.

19. Marrs TC. Toxicology of insecticides to mammals. Pest Manag Sci 2012: 68: 1332-1336.

20. Prullage JB, Tran HV, Timmons $P$ et al. The combined mode of action of fipronil and amitraz on the motility of Rhipicephalus sanguineus. Vet Parasitol 2011; 179: 302-310

21. Baggott D, Ollagnier C, Yoon SS et al. Efficacy of a novel combination of fipronil, amitraz and (S)-methoprene for treatment and control of tick species infesting dogs in Europe. Vet Parasitol 2011; 179: 330-334.

22. Jongejan F, Fourie JJ, Chester ST et al. The prevention of transmission of Babesia canis canis by Dermacentor reticulatus ticks to dogs using a novel combination of fipronil, amitraz and (S)-methoprene. Vet Parasitol 2011; 179: 343-350.

23. Baker CF, Hunter JS III, McCall JW et al. Efficacy of a novel topical combination of fipronil, amitraz and (S)-methoprene for treatment and control of induced infestations with four north American tick species (Dermacentor variabilis, Ixodes scapularis, Amblyomma americanum and Amblyomma maculatum) on dogs. Vet Parasitol 2011; 179: 324-329.

24. Hunter JS III, Baggott D, Everett WR et al. Efficacy of a novel topical combination of fipronil, amitraz and (S)-methoprene for treatment and control of induced infestations of brown dog ticks (Rhipicephalus sanguineus) on dogs. Vet Parasitol 2011; 179: 318-323.

25. Naranjo CA, Busto U, Sellers EM et al. A method for estimating the probability of adverse drug reactions. Clin Pharmacol Ther 1981; 30: 239-245.

26. Bryden SL, Olivry T, White SD et al. Clinical, histopathological and immunological characteristics of exfoliative cutaneous lupus erythematosus in 25 German shorthaired pointers. Vet Dermatol 2005; 16: 239-252.

27. Moriello KA, Behr M. Pemphigus-like drug reaction in a dog after a single application of vetra 3D. Vet Dermatol 2012; 23(Suppl. 1): 77 (abstract).

28. Brenner $S$, Wolf R, Ruocco V. Contact pemphigus: a subgroup of induced pemphigus. Int J Dermatol 1994; 33: 843-845.

29. Tizard IR. Veterinary Immunology: An Introduction. 9th edition. St Louis, MO: Elsevier/Saunders, 2012; 551.

\section{Supporting Information}

Additional Supporting Information may be found in the online version of this article.

Table S1. Treatment approaches used in dogs with localized or generalized form of Certifect-triggered pemphigus foliaceus.

Table S2. Comparison of the treatment outcome between dogs with localized and generalized forms of Certifect-triggered pemphigus foliaceus.

Data S1. Material and Methods.

\section{Résumé}

Contexte - Un ectoparasiticide topique récemment commercialisé et contenant du fipronil, de l'amitraz et du S-méthoprène, a été associé au développement d'une dermatite pustuleuse acantholytique semblable au pemphigus foliacé (PF) lié au Promeris.

Hypothèses/Objectifs - Nos objectifs étaient de décrire les critères cliniques, histologiques et immunologiques de cette réaction cutanée médicamenteuse de type PF.

Sujets - Vingt et un chiens avec un diagnostic définitif ou probable de réaction cutanée médicamenteuse indésirable de type PF ont été identifiés entre mai 2012 et février 2013.

Matériel et méthodes - L'histologie, l'immunofluorescence directe et indirecte ont été les outils utilisés pour atteindre les objectifs de l'étude.

Résultats - La plupart des chiens étaient d'âge moyen ou âgés (médiane, 9 ans) et de grande race (médiane, $23 \mathrm{~kg}$ ). Pour six chiens (29\%), les lésions de type PF restaient confinées au site d'application, alors que 15 chiens (71\%) présentaient des lésions sur des zones à distance. Une ou deux applications de l'ectoparasiticide étaient suffisantes pour entrainer des lésions de type PF pour respectivement sept (33\%) et six (29\%) chiens. Les signes systémiques étaient reportés pour neuf chiens (43\%), toutes les lésions s'étendant à des sites à distance des zones d'application. Les IgG anti-kératinocytes liés au tissu ont été détectés dans l'épiderme lésionnel de huit sur 19 cas (42\%) par immunofluorescence directe alors que les IgG anti-kératinocyte sériques étaient détectés dans 10 sur 14 cas (71\%) par immunofluorescence indirecte. Les autoanticorps dirigés contre la desmocolline-1 canine dans 11 sur 14 cas (79\%) mais pas contre la desmogléine-1 par immunofluorescence indirecte sur cellules transfectées. Ces données immunologiques étaient semblable pour les atteintes locales ou à distance.

Conclusions et importance clinique - Ce nouvel ectoparasiticide topique contenant du fipronil, de l'amitraz et du S-méthoprène peut entrainer le développement d'une dermatose pustuleuse acantholytique semblable d'un point de vue clinique, histologique et immunologique au PF lié au Promeris et au PF d'apparition spontanée chez les chiens. 


\section{Resumen}

Introducción - un ectoparasiticida tópico conteniendo fipronil, amitraz y S-metopreno ha sido asociado con el desarrollo de una dermatitis pustular acantolítica similar a pénfigo foliáceo (PF) inducido por Promeris.

Hipótesis/Objetivos - nuestros objetivos fueron describir las características clínicas, histológicas e inmunológicas de esta reacción cutánea adversa similar a PF.

Animales - veintiún perros con diagnóstico probable o definitivo de reacción adversa cutánea similar a PF identificados entre Mayo del 2012 y febrero del 2013.

Métodos - para conseguir realizar estos objetivos se utilizaron histopatología e inmunofluorescencia directa e indirecta.

Resultados - la mayoría de los perros eran de mediana edad o mayores (mediana 9 años) y de gran tamaño (mediana, $23 \mathrm{~kg}$ ). En seis perros $(29 \%)$, las lesiones permanecieron restringidas a la zona de aplicación, mientras que en 15 perros (71\%) se observaron lesiones distantes. Una o dos aplicaciones del ectoparasiticida fueron suficientes para producir las lesiones similares a PF en siete (33\%) y seis (29\%) perros, respectivamente. Se observaron signos sistémicos en nueve perros (43\%), todos con lesiones distales al lugar de aplicación. Se detectó IgG frente a queratinocitos en el tejido en las lesiones de la epidermis en 8 de 19 casos (42\%) mediante inmunofluorescencia directa, mientras que se detectó lgG frente a queratinocitos en el suero en 10 de 14 casos (71\%) por inmunofluorescencia indirecta. Los autoanticuerpos eran frente a desmocolina-1 en 11 de 14 perros (79\%), pero no frente a desmogleina-1, mediante inmunofluorescencia indirecta de células transfectadas. Estos hallazgos inmunológicos fueron similares en casos con enfermedad localizada y distante.

Conclusiones e importancia clínica - este nuevo ectoparasiticida tópico conteniendo fipronil, amitraz y S-metopreno es capaz de producir el desarrollo de una dermatosis pustular acantolítica que a nivel clínico, histológico e inmunológico es similar a PF producido por Promeris y a PF autoinmune natural.

\section{Zusammenfassung}

Hintergrund - Unlängst wurde ein topisches Ektoparasitikum, welches Fipronil, Amitraz und S-Methopren enthält, gelauncht. Dieses Produkt wurde mit der Entwicklung einer akantholytischen pustulösen Dermatitis ähnlich jener, des durch Promeris ausgelösten Pemphigus foliaceus (PF), in Zusammenhang gebracht.

Hintergrund - Unsere Ziele bestanden darin, die klinischen, histologischen und immunologischen Merkmale dieser PF-ähnlichen kutanen Medikamentennebenwirkung zu beschreiben.

Tiere - Einundzwanzig Hunde mit der möglichen oder definitiven Diagnose einer PF-ähnlichen kutanen Medikamentennebenwirkung wurden zwischen Mai 2012 und Februar 2013 identifiziert.

Material und methoden - Um die Studienziele zu erreichen, wurde die Histologie, sowie die direkte und indirekte Immunfluoreszenz angewendet.

Ergebnisse - Die meisten Hunde waren in mittlerem Alter oder älter (Median 9 Jahre) und große Hunde (Median 23 kg). Bei sechs Hunden (29\%) blieben die PF-ähnlichen Veränderungen auf die Applikationsstelle beschränkt, während 15 Hunde (71\%) Veränderungen auch an entfernten Stellen zeigten. Eine oder zwei Applikationen des Ektoparasitikums waren ausreichend, um die PF-ähnlichen Veränderungen bei sieben (33\%) bzw sechs (29\%) Hunden auszulösen. Systemische Anzeichen wurden bei neun Hunden (43\%) beschrieben, wobei bei allen die Hautveränderungen auch entfernt von der Applikationsstelle auftraten. An Gewebe gebundenes Antikeratinozyten IgG wurde in der läsionalen Epidermis bei acht von 19 (42\%) der Fälle mittels direkter Immunfluoreszenz nachgewiesen, während Serum Antikeratinozyten IgG bei 10 von $14(71 \%)$ der Fälle mittels indirekter Immunfluoreszenz gefunden wurden. Mittels indirekter Immunfluoreszenz auf transfizierten Zellen wurden Autoantikörper gefunden, die auf canines Desmocollin-1 bei 11 von 14 (79\%) Hunden, aber nicht auf Desmoglein-1, abzielten. Diese immunologischen Befunde waren bei lokalisierter und ausgebreiteter Erkrankung ähnlich.

Schlussfolgerungen und klinische Bedeutung - Dieses neue topisch anzuwendende Ektoparasitikum, welches Fipronil, Amitraz und S-Methopren enthält, ist imstande eine akantholytische pustulöse Dermatitis auszulösen, die klinisch, histologisch und immunologisch dem durch Promeris-ausgelösten PF und natürlich vorkommendem autoimmunem PF bei Hunden sehr ähnlich ist. 


\begin{abstract}
摘要
背景 一 最近出台的局部杀外寄生虫药, 含有氟虫腈、双甲脒和 S-甲氧普林, 可能导致皮肤棘层松懈脓疱性

皮炎, 类似于Promeris诱发的落叶型天疮疮。

假设/目的 - 我们的目的是描述PF样皮肤药物副反应的临床、组织学、免疫学特征。

动物 - 2012年五月至2013年二月的21只犬，可能或确诊患有PF样药物不良反应。

材料及方法 一 用组织学、直接和间接免疫苂光测试的方法来进行此项研究。

结果 - 大部分犬处于中老年 (中值为9岁) 并体型偏大 (中值为 $23 \mathrm{Kg}$ ）。6只犬（29\%）, PF样损伤仅限于 上药部位, 然而15只犬 (71\%) 损伤出现在其他部位。一或两种杀外寄生虫药的使用足以导致PF样损伤分别是7 只 (33\%) 和6只（29\%）。出现全身症状的有9例（43\%），其损伤全部从用药部位扩散至远端皮肤。直接免疫 苂光实验显示, 19 只患犬中的8只 (71\%) 损伤的上皮中发现了抗角质形成细胞组织结合IgG, 间接免疫苂光实 验显示14只患犬中有10只（79\%）血清中有抗角质形成细胞IgG。14只犬中有11只犬（79\%）的自身抗体中发现 桥粒胶蛋白 -1 , 但在间接免疫苂光试验转染细胞中, 没有发现桥粒芯蛋白-1。在上药部位发病和其他部位发病 患犬的免疫学发现相似。

结论与临床意义 - 含氟虫腈、双甲脒和S-甲氧普林的新的杀外寄生虫药, 能够引起棘层松解脓疮病, 其发 展, 临床、组织学和免疫学接近于Promeris引起的犬PF和自发性自体免疫PF。
\end{abstract}

\title{
要約
}

背景 - 最近発売されたフィプロニル、アミトラズ、およびSーメトプレンを含有する外用外部寄生虫駆除剂 はPromeris誘発性落葉状天疮瘡 $(\mathrm{PF})$ に類似した棘融解性膿疮性皮膚炎の発生と関連している。

仮説/目的 - 筆者らの目的はこのPF様薬物有害反応の皮膚臨床的、組織学的、免疫学的な特徵を解説する こと。

供与動物 - 21頭の犬が2012年5月から2013年2月の間にPF様皮膚薬物有害反応が推定あるいは確定診断され た。

材料と方法 - 組織学、直接および間接免疫蛍光法を研究の目的を検討する為に用いた。

結果 - ほとんどのイヌは中年齢あるいはそれ以上の年齞(平均、9歳)および大型犬 (平均、23kg)であった。 6頭 (29\%) ではPF様病変は塗布部位に限定して存在していた一方、15頭 $(71 \%)$ では離れた部位に病変を示して いた。外部寄生虫駆除剤の1度あるいは2度の塗布はそれぞれ 7 頭 $(33 \%)$ と6頭 $(29 \%)$ でPF様病変を誘発するの に十分であった。全身症状が9頭(43\%) で報告され、その全てのイヌで塗布部位から離れた部位まで病変が広 がっていた。抗ケラチノサイトIgGの組織結合が、直接免疫蛍光法にて19 症例中 8 頭 (42\%) で病変部上皮から 検出された一方、血清抗ケラチノサイトIgGは間接免疫蛍光法により14頭中10頭 (71\%)で検出された。自己抗 体は14頭中 11 頭 $(79 \%)$ でイヌデスモコリンー 1 を標的としていることが判明したが、形質転換した細胞におけ る間接免疫抗体によって自己抗体はイヌデスモグレイン-1を標的としていなかった。これらの免疫学的所見 は限局したおよび遠隔病変の疾患の症例で類似していた。

結論および臨床的な重要性 - この新しいフィプロニル、アミトラズ、ならびにS-メトプレン含有の外用外 部寄生虫駆除剂はイヌにおいて臨床的、組織学的、免疫学的にPromeris-誘発性PFおよび自然発症性自己免 疫性PFに類似した棘融解性膿疮性皮膚症を発生する誘因となることがある。 